\title{
MAGEC2 Gene
}

National Cancer Institute

\section{Source}

National Cancer Institute. MAGEC2 Gene. NCI Thesaurus. Code C104527.

This gene may enhance ubiquitin ligase activity. 